\title{
Michał Krotoszyński
}

Adam Mickiewicz University in Poznań (Poland)

\section{Transitional Justice Models and Analytic Philosophy: Towards Theory}

\begin{abstract}
As an interdisciplinary field of scholarship, transitional justice is still in its pre-theoretical stage, focusing mainly on the case and comparative studies, supported with general considerations concerning justice in the times of transition. To entrench the field as a distinct area of studies, a theory of transitional justice needs to be formulated. The article explores the possibility of making a step towards such a theoretical basis with the use of the tools of analytical philosophy, methodology and legal theory. First, drawing on Leszek Nowak's procedure of idealisation, three basic models of responses to a painful past are formulated. Then, distinct transitional justice values are attributed to each of the models. Finally, with the use of Jerzy Kmita's concept of humanistic interpretation, the article seeks to conceptualize the way in which these values - among other factors, such as the need to uphold the rule of law or to preserve the stability of a democratic system - influence the choice of a model of transitional justice response. Thus, the aim of the presented models - which I described in more detail elsewhere (Krotoszyński 2017) - is to provide a sound theoretical basis for some of the fundamental claims formulated in the field of transitional justice.
\end{abstract}

Keywords: transitional justice; analytic philosophy; models; idealisation; humanistic interpretation; values

\section{Introduction}

Despite its rapid development in the last thirty years, transitional justice as a field of scholarship is still in its pre-theoretical stage. Even though the amount of literature on dealing with the past is substantial, still the majority of it is comprised of the case and comparative studies or general considerations concerning justice in the times 
of transition. As there are few works that are largely theoretical - notable examples include the works by Kritz (1995), Teitel (2000), Elster (2004), Murphy (2017) and the books edited by Williams, Nagy \& Elster (2012) and Buckley-Zistel et al. (2014) - there is a need to create a common ground for different types of discourse present in the field and to "rework available material with an attempt to create some theoretical framework for transitional justice" (Czarnota 2013, p. 50). The theorisation of transitional justice is crucial, as it can foster a better understanding of this complex field, enable the more precise use of the employed conceptual notions and provide practitioners with a certain knowledge concerning the paradigms used in the times of transition (Buckley-Zistel et al. 2014, p. 3-4). A step towards this goal can be achieved with the use of the tools formulated by Jerzy Kmita and Leszek Nowak, Polish methodologists and analytic philosophers. As Nowak (1971, p. 56) noted, in advanced empirical sciences, the construction of idealisation laws is necessary. As the creation of models is, in fact, an idealisation procedure, the article aims to make a move towards the theorisation of transitional justice by exploring detailed models that can be formulated in this diverse, interdisciplinary field.

Transitional justice can be understood as the concept of justice which is concerned with the treatment of the wrongdoers and the victims of human rights abuses conducted before a liberalising political change. Even though this definition puts emphasis on the ethical dimension of dealing with past wrongs, the complex phenomenon of transitional justice can be analyzed on at least three levels: (1) the level of legal and non-legal means used by countries in the transitional period to face the past, (2) the level of the axiological justifications of such mechanisms, including values and the principles of justice, and (3) the level of the decisions to implement various transitional justice instruments, based both on the values and other, non-axiological factors. Those three levels of transitional justice are inter-connected as through political decisions the values are transposed to legal and social institutions (Krotoszyński 2017). The articulation of values fundamentally different from the ones supported by a previous authoritarian regime is believed to create a normative shift that legitimises a new democratic order and fosters the trust of the public in the proliferation of basic human rights norms (Teitel 2000; de Greiff 2012; Młynarska-Sobaczewska 2010).

The article follows the abovementioned structure of transitional justice. First, drawing on Leszek Nowak's procedure of idealisation, three descriptive models of responses to a difficult past are formulated. Then, distinct transitional justice values are indicated and, in part, attributed to each of the models. Finally, with the use of Jerzy Kmita's concept of humanistic interpretation, the article aims to conceptualize the way in which the values directly connected with dealing with the past - among other values, such as the need to uphold the rule of law or to preserve the stability of 
a democratic system - influence the choice of a model of transitional justice response. After presenting the models of transitional justice decision-making, the text discusses their limits and possible further developments.

\section{Idealization and Three Models of Transitional Justice Response}

According to Nowak, in the process of idealisation - a basic procedure common in all developed empirical fields of science - the researchers create models of phenomena present in the real world. A model can be defined as an intentionally simplified image of a fragment of reality. To create such a model, a scientist needs to list the determinants that influence the phenomena under scrutiny and divide them between important, principal factors and insignificant, secondary ones. Then the scientist adopts idealising conditions, which counterfactually state that the secondary factors do not exist at all. It allows for a formulation of an idealisation law, which describes the relations between the principal factors. Examples of such laws include Galileo's law of free fall - which abstracts, e.g. from air friction or disturbances in a gravitational field - or Marx's theory of value. An idealisation law can later be concretised, as some of the idealising conditions can be removed, thus making it necessary to take into account some of the secondary factors which were previously ignored (Nowak 1971, 1974a, 1977, 1992).

Idealizing conditions can be applied not only to relations between objects but also to the objects themselves. Therefore a scientist can assume that an idealised item has different characteristics than a factual one. Such non-existent objects, stripped of their secondary features and enriched with fictional characteristics, can be called ideal types. Thus, an ideal type is a model of an existing object (or objects) which (1) is equipped with a feature of maximal or minimal magnitude that, to such extent, does not exist in factual items and (2) has only those features of factual items that are consistent with this borderline feature (Nowak 1971, p. 43). Examples of such ideal types include an ideal gas, a black body or a closed economy.

The creation of models through the use of an idealisation procedure can also be used in the field of transitional justice. Even though the answer to the legacy of human rights abuse is different in each transitional society, the similarities between the states allow for the creation of the models of transitional justice response (see Garrett 2000 and Eser, Arnold \& Kreicker 2001 for other examples of such models). If one decides to take into account the mechanisms that concentrate on committed human rights violations and their perpetrators, the principal factors may include: (1) criminal sanctions against political and military leaders responsible for the abuses and against direct perpetrators that acted on their orders or with their direct or indirect consent; 
(2) amnesties for the abovementioned individuals; (3) truth-seeking mechanisms that aim to create the account of historical events on state, regional or individual level and (4) the use of administrative procedures, such us vetting or purges.

In this case, the reparations for victims will be perceived as a secondary factor and will be abstracted from. This is not to indicate that financial or symbolical compensation is unimportant: on the contrary, the significance of holistic response to a difficult past, including victims recognition, is unquestioned and emphasized in transitional justice literature (see inter alia: United Nations Security Council [UNSC] 2004, para. 26; de Greiff 2012, p. 34-39; Murphy 2017, p. 160-192). Reparations for victims are in no way alternative to the means concentrating on the wrongdoers, as they can - and in fact: should - coexist with each of the instruments listed above. As the explanatory strength of the models lies in highlighting the differences between transitional justice responses, compensation mechanisms will be deliberately abstracted from to underline these distinctions.

Taking into account the instruments used to face the past, three descriptive models of transitional justice response can be formulated: (1) the retribution model; (2) the historical clarification model and (3) the thick line model. The presented models should be considered ideal types. Although it is possible to attribute some of the case studies to one of the three models, in most cases the response used in a certain country will prove to be a mixture of the types described below.

In the retribution model those responsible for actions condemned in a new democratic order are subject to sanctions. These may include criminal punishments imposed by either domestic courts or international or hybrid tribunals and penalties enforced through administrative measures, including vetting and purges. The reduction of pensions of those involved in the former regime can also be attributed to this ideal type. Among the examples of this model are criminal trials and vetting in East Germany (Wilke 2007; Zajadło 2003), decommunization purge in the Czech Republic (Přibán 2007) and the dissolution of Polish communist secret police and the reduction of pensions of its former personnel (Krotoszyński 2017, p. 115-118).

In the historical clarification model the government refrains from using formal sanctions. Instead, truth-seeking initiatives are implemented. Those may be further divided into the mechanisms of collective and individual clarification. The former include truth commissions, perpetual national memory institutes and memorialization initiatives, such as the enactment of monuments, the creation of museums and public apologies by the government (for more on memorialization see: Wolff-Powęska 2011; Marszałek-Kawa et al. 2017a, 2017b). Among individual clarification instruments, lustration and declassification of former secret police files are most common. Even though the lack of formal punishment is typical for this model, the government may 
resort to sanctions against those who fail to participate in truth-seeking initiatives or intentionally distort the memory of past events. The examples of this ideal type include the work of the Guatemalan truth commission (CEH 1999), Polish lustration (Czarnota 2007; Krotoszyński 2014) and the reckoning with apartheid in South Africa (TRC 1998; Dyzenhaus 1998; de Bois-Pedain 2007; Smolak 2002).

Finally, in a model where a "thick line" is drawn to mark off the past, the government refrains from using either sanctions or instruments of historical clarification. Instead, legal or factual amnesties are implemented. Post-Francoist Spain until 2007 (Garrett 2000) and post-Soviet Russia (Andrieu 2011) can be listed as main examples of this ideal type.

\section{Transitional Justice Values}

Even though transitional justice is inherently connected with political realities, it is in the times of transition that political decisions often have an important moral dimension. The analysis of the instruments used to confront the past, reasons for their implementation and the literature on the subject allows to identify certain transitional justice values that may be pursued through the use of the means of dealing with the past (for a definition of a value see e.g.: Nowak 1974b, p. 7-34). As transitional justice is both past and future-oriented, one can distinguish (1) values connected with dealing with the past and (2) values related to the creation of a new political order.

Values directly linked with overcoming the past can be further divided into three groups: (1) just retribution for previous wrongs, (2) truth, memory and acknowledgement of the past and (3) social inclusion, mercy and forgiveness. The calls for justice ever-present in the times of transition - are in fact often calls for a just punishment which is hoped to reinforce basic human rights norms, reinstall social balance and redress the victims. The resolutions establishing ad hoc tribunals for Former Yugoslavia and Rwanda both stated that 'bringing to justice' those responsible for human right abuses should ensure that such violations are halted and effectively redressed (UNSC 1993; 1994). Some of the victims also state that remembering is not enough and that 'memorials without justice are simply monuments to remind the victims of the perpetrators' power' (Cabrera 1998). Thus, the value of just punishment can be pursued through the retribution model. Secondly, the truth about past events - itself often portrayed as a developing human right (United Nations Economic and Social Council 2006; Lachowski 2013) - together with an official acknowledgement of past wrongs can be seen as a sign of respect for the victims and a source of honest public history and social identities (Hayner 2001, p. 24-27; Wolff-Powęska 2011, p. 51-53). Even though criminal trials are a way of an official acknowledgement of past wrongs, 
these values can be sought mainly through the instruments typical for the historical clarification model. Finally, social inclusion, mercy and forgiveness can be perceived as values leading to the reconstruction of social bonds and as virtues distinguishing the new order from the previous regime (Mazowiecki 2009; Afri-Forum and Another v. Malema and Others 2011, para. 18). This group of values can be pursued through amnesties typical for the thick line model.

Among values related to the creation of a new political order, within the context of a democratization - a paradigmatic case of transitional justice - one can further distinguish: (1) the values connected with the sole existence of peace, political stability and free democratic elections and (2) the values of a mature democracy based on the rule of law and respect for international human rights law. As de Greiff (2012, p. 55) points out: "it is not that democracies have a spotless human rights record, but on the whole, they fare better on the protection of basic human rights than their alternatives". Therefore the stability of a democratic system respecting the individual and collective rights is an important value in itself. Yet, the final goal of a democratic transition should be to "create pluralist democracies, based on the rule of law and respect for human rights and diversity" (Council of Europe Parliamentary Assembly [CEPA] 1996, para. 2), which is an objective far more ambitious than peace and the entrenchment of democratic procedures. In such a system, an individual has a specific position of a rights-bearing citizen who can trust that both the state and other society members will uphold basic human right norms (de Greiff 2012). Of course, if the goal of a political transformation is not a liberal democracy but a different political system, the values connected with a new political order may differ from the ones presented above.

\section{Humanistic Interpretation and the Models of Transitional Justice Decision-Making}

One of the main goals of humanistic studies is to explain the rationales that lay behind various human activities. Despite the fact that those inquiries are often coined in psychological terms, the researchers - whether it is history, literature or visual arts do not, in fact, engage in the psychological study of the motives of the individuals in question. Instead, according to Jerzy Kmita (1971; see also Kmita \& Nowak 1968, 1970), the scientists in humanities base their research, albeit often unconsciously, on the idea of a rational subject. For instance, in order to explain why Napoleon decided to invade Russia in 1812, the scientists do not engage in the somewhat improbable task of analyzing Napoleon's mental state, but instead construct a notion of a rational subject that, equipped with the knowledge and values that can be attributed to $\mathrm{Na}$ - 
poleon, would rationally arrive at this ultimately disastrous decision. This way of explaining why a certain action occurred is known as humanistic interpretation.

According to the rationality assumption, which serves as a base of humanistic interpretation, if in a specific moment in time " $X$ has to undertake one of the actions $C 1, \ldots, C$ n, which according to his knowledge (...) exclude each other and add up (all) together, and unfailingly lead to the results $S 1, \ldots, S$ m respectively (while $m \leq n$ ), and the said results $S 1, \ldots, S \mathrm{~m}$ are ordered by the relation of preference characteristic for $X^{\prime \prime}$, then $X$ will undertake the action that leads to the result that has the highest preference, i.e.: the result that $X$ prefers the most (Kmita \& Nowak 1968, p. 51). This outcome does not have to be morally defensible: it is just a state of affairs that $X$ - reasonably or not - praises the most. If the researcher also knows that a certain result $S \mathrm{k}$ has the highest preference for $X$ and that $X$ knows that the action $C \mathrm{k}$ unfailingly leads to the result $S \mathrm{k}$, then the scientists can finally explain why $X$ decides to take the action $C \mathrm{k}$.

One should note, however, that the rationality assumption must be regarded as an idealisation claim in the meaning presented above (Kmita 1971; Nowak 1970). It is not only because it counterfactually presumes a definite link between an action and a result - whereas in most cases the result is only probable - but also because it involves idealising assumptions regarding the knowledge and the preferences of the subject, including a linear order of the values $X$ praises. It also means that the rationality assumption can be concretised as some of the idealisations are removed. It, in turn, will usually complicate the consequent of the rationality assumption (for a list of idealising conditions and concretisations see: Patryas 1979).

The procedure of humanistic interpretation can be used in the field of transitional justice as a means of explaining why a particular response to the past was implemented in a certain country. Here the state (or the lawmaker) is understood as a subject that rationally tries to confront the past. The actions $C 1, \ldots, C$ represent the implementation of different mechanisms used in this process or - in a broader perspective - the use of a distinct model of transitional justice response. The results ordered by the relation of preference include certain transitional justice values. Therefore, in the models presented below, the state chooses a particular response to the past to fulfil specific transitional justice values (for a fuller methodological account see: Krotoszyński 2017, p. 214-220). Depending on the set of values taken into account, one may create models with a different degree of concretisation.

I. In the most basic model - the model with the highest degree of idealisation the only values considered are the ones directly connected with dealing with the past. On this level of idealisation, the retribution model is going to be chosen, if the lawmaker prefers the value of just punishment over other values. If the state favours 
truth and acknowledgement, the historical clarification model will be implemented. If the values of social inclusion, mercy and forgiveness are preferred, the thick line model will develop.

II. If, apart from the above values, one also takes into account the value of upholding the rule of law, a much more complicated model will emerge. In general, both just retribution and historical clarification are in line with the rule of law. In order to comply with it, the sanctions should be individual instead of the collective (CEPA 1996, para. 12). It is also forbidden to use retroactive criminal sanctions, although retroactive administrative measures, such as vetting, may be used for a limited period (Ždanoka v. Latvia 2006, para. 118, 135). When it comes to historical clarification, the use of collective clarification measures is more probable if the human rights violations were not documented before the transition; if such documents exist, the state is more likely to use individual clarification measures in order to fulfil the obligation to investigate the past (Teitel 2000, p. 92-95). On the other hand, an amnesty for serious human rights violations - a tool of a thick line model - is in general inconsistent with the rule of law (for a discussion on acceptable amnesties see, e.g., UNSC 2004, para. 10, 64; Laplante 2009; Lachowski 2014).

Taking this into account, we may alter the model formulated above. Thus, if the legislator dedicated to the rule of law has the highest preference for just punishment, the retribution model is going to develop with the use of individualised legal sanctions, but without resorting to retroactive criminal measures. If the legislator favours truth and acknowledgement, the model of historical clarification will be created either by employing collective truth-seeking initiatives or individual clarification instruments (depending on historical circumstances). Only if the state prefers social inclusion, mercy and forgiveness over the combined values of the rule of law and just punishment or truth and acknowledgement, the thick line model is going to develop.

III. An even more complicated model can be formulated, if one takes into account the value of the adherence to international human rights law. The influence of international law is twofold. First, the punishment is required for certain crimes under international law, including genocide, torture or forced disappearance. Thus, the scope of acceptable amnesties is limited. Second, international law narrows the extent of permittable punishments.

Therefore, if the lawmaker accepts the value of international law, the retribution model based on the sanctions consistent with the rule of law and international norms is going to develop if the actions in questions were crimes under international law - or if they did not have such a status, but the lawmaker favors just punishment over other transitional justice values. The historical clarification model will occur if the deeds were not international crimes and the lawmaker has the highest regard for 
truth and acknowledgement. Finally, if the lawmaker prefers social inclusion, mercy and forgiveness over other vales - including, in case of international crimes, the value of adherence to international law - the thick line model will be implemented.

IV. Finally, one can take into account the value of the stability of a newly established political order. During fundamental political change, the introduction of an amnesty for the individuals responsible for human rights violations may be a sine qua non-condition of peace or democratisation. As Hansen (2011, p. 5) notes, in these circumstances "new leadership will be predisposed to support transitional justice to the extent that such processes will not conflict with other top priorities of the new leadership, including, but not limited to, maintaining its stability". Therefore, the retribution model will emerge only if the use of sanctions does not endanger peace or democracy and the lawmaker is willing to implement them either because just retribution is favoured or because the actions in question were crimes under international law. If the actions did not have such a status and the state prefers the value of truth, the historical clarification model will develop, provided such a clarification does not jeopardise the transition. If the use of the abovementioned mechanisms is capable of threatening the new order, the lawmaker is likely to implement the thick line model.

\section{The Models of TJ Decision-Making: Meaning, Limits and Possible Developments}

After formulating the models of transitional decision-making, a couple of remarks are in order. The use of humanistic interpretation is value-oriented, as the choice of a distinct action is guided by the preference of values. Therefore, the question stands whether such a procedure is valid for an examination of political phenomena, especially if one takes a less idealistic perspective and concentrates on realpolitik. I would like to argue that if one accepts a broad definition of value - understood here as any outcome assessed by the subject in question, even an immoral one - then the humanistic interpretation is capable of including, at later stages of concretisation, many other factors influencing the transitional justice response. For instance, the fact that a transitional justice measure may be perceived as a weapon in a political struggle (Nalepa 2009) can be taken into account, if the set of values is widened to include the will of the ruling party to remain in power. If such a set of values is extended to contain economic or political benefits that may be gained at the international level, the models can also cover how the governments choose to implement transitional justice measures to please foreign donors. Therefore the instrumentalisation of transitional justice can also be recognised in the models. 
Other factors acknowledged in transitional justice literature can be accounted for differently. The nature of the previous regime (Kitschelt et al. 1999), including the characteristics of its repression (Nedelsky 2004) are the facts that are likely to influence the preference of the values as "what is deemed just is contingent and informed by prior injustice" (Teitel 2000, p. 6). If one removes the idealizing condition according to which actions unfailingly lead to their results, then the political circumstances of a transition (Huntington 1993; Murphy 2017, p. 66-70) may be included in the model, as there exists a direct link between the probability that an instrument of transitional justice will lead to the realization of certain goals and the probability that such a mechanism will be implemented.

Nevertheless, it would be wrong to assume that the presented models have no limits when it comes to the factors they may recognise. Even though emotions can significantly influence the response to a problematic past (Elster 2004, p. 216-244), their inclusion in the models could conflict with the rationality assumption. What is more, the models can be used to explain why a certain actor (lawmaker or other) decides to introduce or to support a specific instrument of dealing with the past or a model of transitional justice response. Even though such an actor may accept and internalise the values supported by other actors, the models cannot describe the complex interrelations that occur between them.

It has to be stressed that the models of transitional decision-making are purely descriptive and do not seek to suggest that there exists a one-size-fits-all outcome the legislator should arrive at. Nor do they wish to prescribe particular actions to the practitioners in the field, although the policymakers should benefit from a certain knowledge they offer. The purpose of the models - despite the high level of their idealisation - is to explain the implementation of specific tools of transitional justice response by linking the mechanisms used to confront the past and the values important in the transitional period. Nevertheless, even if in some cases the factual lawmaker turns out to have a different set or order of values, it will not invalidate the use of humanistic interpretation in the field of transitional justice. It is because the main contribution the use of this procedure brings to the examination of transitional phenomena is that it grounds transitional justice research in the theories of rational behaviour, thus moving the field one step towards the theoretical phase. Therefore, even though the choice on how to confront the past is in fact made more dynamically, reflecting the lack of a stable linear order when it comes to transitional justice values, the analysis of such a decision-making process - also possible with the use of analytic philosophy (Krotoszyński 2016) - should prove complementary to the models presented above.

Being based on humanistic interpretation, the models offer a way in which the relations between the main mechanisms and the goals of transitional justice can be 
described in a scientifically certain way. As they cover the core of transitional justice spectrum and can be widened to include the majority of other factors, the models can help to provide a soundproof for some of the most basic assumptions in the field. Thus, the models allow regarding some of those assumptions as scientific, in a true, methodological meaning of the word.

\section{Concluding Remarks}

Whether a specific model accurately explains transitional justice phenomena can be open for debate. Nevertheless, it is clear that the creation of a theoretical framework for transitional justice is crucial, as the field can only be regarded independent if it rests firmly on some broader philosophical, political or social theory. The models presented above seek to serve as a link between the field of transitional justice and basic methodological tools created by an analytical philosophy.

\section{References:}

Afri-Forum and Another v Malema and Others, South Africa Equality Court, no. 20968/2010, judgement of 12 September 2011.

Andrieu, K. (2011). "An Unfinished Business: Transitional Justice and Democratization in PostSoviet Russia". The International Journal of Transitional Justice, 5 (2), 198-220.

Bois-Predain, du, A. (2007). Transitional Amnesty in South Africa. Cambridge: Cambridge University Press.

Buckley-Zistel, S., Koloma Beck, T., Braun, Ch., \& Mieth, F. (2014). Transitional Justice Theories. Oxon: Routledge.

Cabrera, R. (1998). Should we remember? Recovering historical memory in Guatemala. In: Hamber B. (ed.), Past Imperfect: Dealing with the Past in Northern Ireland and South Africa, 25-30. Derry-Londonderry: INCORE.

CEH (La Comisión para el Esclarecimiento Histórico) (1999). Guatemala, Memory of Silence, Tzininil na 'tab'al. Report of the Commission for Historical Clarification, conclusions and recommendations. Available at: https://www.aaas.org/sites/default/files/migrate/uploads/mos_en.pdf.

Council of Europe Parliamentary Assembly (1996). Resolution 1096 (1996) on measures to dismantle the heritage of former communist totalitarian systems, CoE Doc. 1096 (27 June 1996).

Czarnota, A. (2007). The Politics of the Lustration Law in Poland, 1989-2006. In: Mayer-Rieckh, A., \& de Greiff, P. (eds.), Justice as Prevention: Vetting Public Employees in Transitional Societies, 222-258. New York: Social Science Research Council.

Czarnota, A. (2013). "On the Beauty of Confusions or Transitional Justice, and Rule of Law". Law of Ukraine: Legal Journal, 4, 47-53.

Dyzenhaus, D. (1998). Judging the Judges, Judging Ourselves. Truth, Reconciliation and the Apartheid Legal Order. Oxford: Hart Publishing. 
Elster, J. (2004). Closing the Books: Transitional Justice in Historical Perspective. Cambridge: Cambridge University Press.

Eser, A., Arnold, J., \& Kreicker, H. (2001). Criminal law in reaction to state crime: comparative insights into transitional processes; a project report. Freiburg: Max-Planck-Institut für ausländisches und internationales Strafrecht. Available at: http://www.freidok.uni-freiburg.de/volltexte/6349/

Garrett, S. A. (2000). Models of Transitional Justice - A Comparative Analysis. Report submitted to the Conference International Studies Association 40 Annual Convention, Los Angeles (14-18 March 2000).

de Greiff, P. (2012). Theorizing Transitional Justice. In: Williams, M. S., Nagy, R., \& Elster, J. (eds.), Transitional Justice, 31-77. New York-London: NYU Press.

Hansen, T. O. (2011). “Transitional Justice: Toward a Differentiated Theory”. Oregon Review of International Law, 13, 1-54.

Hayner, P. B. (2002). Unspeakable Truths: Facing the Challenge of Truth Commissions. New YorkLondon: Routledge.

Huntington, S. (1993). The Third Wave: Democratization in the Late Twentieth Century. Norman: University of Oklahoma Press.

Kitschelt, H., Mansfeldova, Z., Markowski, R., \& Tóka, G. Post-Communist Party Systems: Competition, Representation, and Inter-Party Cooperation. Cambridge: Cambridge University Press.

Kmita J., \& Nowak L. (1968). Studia nad teoretycznymi podstawami humanistyki. Poznań: Uniwersytet im. Adama Mickiewicza w Poznaniu.

Kmita, J., \& Nowak, L. (1970). „The Rationality Assumption in Human Sciences”. The Polish Sociological Bulletin, 1, 43-68.

Kmita, J. (1971). Z metodologicznych problemów interpretacji humanistycznej. Warszawa: Państwowe Wydawnictwo Naukowe.

Kritz, N. J. (ed.) (1995). Transitional Justice: How Emerging Democracies Reckon with Former Regimes, Volume I: General Considerations. Washington: US Institute of Peace Press.

Krotoszyński, M. (2014). "Polish lustration and the models of transitional justice". Adam Mickiewicz University Law Review, 3, 199-211.

Krotoszyński, M. (2016). "The Transitional Justice Models and the Justifications of Means of Dealing with the Past”. Oñati Socio-legal Series, 6 (3), 584-606.

Krotoszyński, M. (2017). Modele sprawiedliwości tranzycyjnej. Poznań: Wydawnictwo Naukowe UAM.

Lachowski, T. (2013). Prawo do prawdy podstawowym prawem cztowieka? Refleksje na temat sprawiedliwości okresu przejściowego (transitional justice). Warszawa: Instytut Badań nad Stosunkami Międzynarodowymi.

Lachowski, T. (2014). Sprawiedliwość czy bezkarność? Legalność amnestii w świetle prawa międzynarodowego. In: Stachowiak, G. (ed.), Stosunki międzynarodowe: Regiony, historia, problemy, 157-169. Kraków: Koło Studentów Stosunków Międzynarodowych UJ.

Laplante, L. J. (2009). "Outlawing Amnesty: The Return of Criminal Justice in Transitional Justice Schemes”. Virginia Journal of International Law, 49, 915-984.

Marszałek-Kawa, J., Piechowiak-Lamparska, J., Ratke-Majewska, A., Wawrzyński, P. (2017a). The Politics of Memory in Post-Authoritarian Transitions, Volume One - Case Studies. Cambridge: Cambridge Scholars Publishing. 
Marszałek-Kawa, J., Wawrzyński, P., Ratke-Majewska, A. (2017b). The Politics of Memory in Post-Authoritarian Transitions, Volume Two - Comparative Analysis. Cambridge: Cambridge Scholars Publishing.

Marszałek-Kawa, J., \& Wawrzyński, P. (2016). "Remembrance, Identity Politics and Political Transitions: a Comparative Study”. Polish Political Science Yearbook, 45, pp. 11-21. DOI: http://dx.doi.org/10.15804/ppsy2016001.

Mazowiecki, T. (2009). Sąd nad gruba linia. Wyborcza.pl. Available at: http://wyborcza.pl/magazyn/ 1,124059,7030199,Sad_nad_gruba_linia.html.

Młynarska-Sobaczewska, A. (2010). Autorytet państwa. Legitymizacyjne znaczenie prawa w państwie transformacji ustrojowej. Toruń: Towarzystwo Naukowe Organizacji i Kierownictwa „Dom Organizatora”.

Murphy, C. (2017). The Conceptual Foundations of Transitional Justice. Cambridge: Cambridge University Press.

Nalepa, M. (2009). "Lustration and Survival of Parliamentary Parties". Taiwan Journal of Democracy, 2 (5), 45-68.

Nedelsky, N. (2004). "Divergent responses to a common past: Transitional justice in the Czech Republic and Slovakia”. Theory and Society, 33, 65-115.

Nowak, L. (1970). „Teorie racjonalnego zachowania jako teorie modelowe”. Studia Metodologiczne, 7, 59-89.

Nowak, L. (1971). Upodstaw Marksowskiej metodologii nauk. Warszawa: Państwowe Wydawnictwo Naukowe.

Nowak, L. (1974a). “O jednorodności pojęcia modelu”. Neodidagmata, 6, 61-69.

Nowak, L. (1974b). U podstaw marksistowskiej aksjologii. Warszawa: Państwowe Wydawnictwo Naukowe.

Nowak, L. (1977). Wstęp do idealizacyjnej teorii nauki. Warszawa: Państwowe Wydawnictwo Naukowe.

Nowak, L. (1992). The idealizational approach to science: a survey. In: Brzeziński, J., \& Nowak, L. (eds.), Idealization III: Approximation and Truth, 9-63. Amsterdam-Atlanta: Rodopi.

Patryas, W. (1979). Idealizacyjny charakter interpretacji humanistycznej. Poznań: Wydawnictwo Naukowe UAM.

Přibáń, J. (2007). Oppressors and Their Victims: The Czech Lustration Law and the Rule of Law. In: Mayer-Rieckh, A., \& de Greiff, P. (eds.), Justice as Prevention: Vetting Public Employees in Transitional Societies, 308-346. New York: Social Science Research Council.

Smolak, M. (2002). „Sprawiedliwość transformacyjna na przykładzie Komisji Prawdy i Pojednania Republiki Południowej Afryki”. Państwo i Prawo, 11, p. 66-73.

Teitel, R. G. (2000). Transitional Justice. Oxford-New York: Oxford University Press.

TRC (Truth and Reconciliation Commission of South Africa) (1998). The TCR Report. Available from: http://www.justice.gov.za/trc/report/index.htm.

United Nations Economic and Social Council (2006). Promotion and Protection of Human Rights. Study on the right to the truth. Report of the Office of the United Nations High Commissioner for Human Rights, UN Doc E/CN.4/2006/91 (8 February 2006).

United Nations Security Council (1993). Security Council Resolution 827 (1993), UN Doc S/ RES/827 (25 May 1993). 
United Nations Security Council (1994). Security Council Resolution 955 (1994), UN Doc S/ RES/955 (8 November 1994).

United Nations Security Council (2004). The rule of law and transitional justice in conflict and post-conflict societies. Report of the Secretary-General, UN Doc S/2004/616 (23 August 2004).

Wilke, Ch. (2007). The Shield, the Sword and the Party: Vetting the East German Public Sector. MayerRieckh, A., \& de Greiff, P. (eds.), Justice as Prevention: Vetting Public Employees in Transitional Societies, 348-400. New York: Social Science Research Council.

Williams, M. S., Nagy, R., \& Elster, J. (eds.) (2012). Transitional Justice. New York-London: NYU Press.

Wolff-Powęska, A. (2010). Pamięć - brzemię i uwolnienie. Niemcy wobec nazistowskiej przesztości (1945-2010). Poznań: Zysk i S-ka.

Zajadło, J. (2003). Odpowiedzialność za Mur. Procesy strzelców przy Murze Berlińskim. Gdańsk: Arche.

Ždanoka v. Latvia, ECtHR, no. 58278/00, judgement of 16 March 2006.

\section{Author}

Dr Michał Krotoszyński

Adam Mickiewicz University in Poznań, Chair of Theory and Philosophy of Law. Contact details: ul. Św. Marcin 90, 61-809 Poznań, Poland; e-mail: michal.krotoszynski@amu.edu.pl. 